\title{
Executive Compensation and Independent Directors in Japan
}

\author{
Takashi BuI ${ }^{\text {a) }}$
}

\begin{abstract}
Following the example of the United States, Japanese companies have been appointing more independent outside directors in recent years. Independent outside directors are regarded as playing a key role in determining executive compensation and other managerial oversight functions. Prior research mostly supports this idea with respect to U.S. corporations. However, some studies are more skeptical. Therefore, in response to a prior study on U.S. corporations by Chhaochharia and Grinstein (2009), this paper takes a sample of 322 Japanese non-financial corporations in the TOPIX 500 index that met certain criteria and analyzes the effect that having more independent directors has had on executive compensation. However, unlike in prior studies, we did not observe a statistically significant effect. In fact, we saw that executive compensation levels were affected more by the structure of executive remuneration that is determined across a company as a whole than by the composition of its board of directors.
\end{abstract}

Keywords: independent director, executive compensation, corporate governance, board control

a) Graduate School of Economics, University of Tokyo, Hongo, Bunkyo-ku, Tokyo, Japan, buitakashi326@icloud.com

A version of this paper was presented at the ABAS Conference 2020 Winter (Bui, 2020).

(C) 2020 Takashi Bui. This is an Open Access article distributed under the terms of the Creative Commons Attribution License, which permits unrestricted reuse, distribution, and reproduction in any medium, provided the original work is properly cited. 


\section{Introduction}

Following the example of the United States, Japanese companies have been rapidly adding independent directors, as suggested by the Corporate Governance Code released in June 2015. The ratio of companies listed on the First Section of the Tokyo Stock Exchange having two or more independent directors, which was $21.5 \%$ in 2014 , had risen to $93.4 \%$ by 2019 (Tokyo Stock Exchange, 2019).

The practice of having independent directors started in the U.S. in 2003. Having external directors to provide oversight of management has existed in the U.S. since the 1950s. The reasoning behind it is that outside directors should be able to provide appropriate management oversight and assessment because they do not have a direct vested interest in the management of a company. This is particularly important in the setting of executive compensation (Fama, 1980; Fama \& Jensen, 1983). However, the Sarbanes-Oxley Act was enacted in 2002 after it was realized that legislation needed to be overhauled to strengthen corporate governance in the wake of such incidents as the 2001 accounting fraud at Enron, which had several outside directors on its board (Maruyama, 2006). In response, the New York Stock Exchange (NYSE) tightened its definition of what constitutes the "independence" of outside directors and started to require that independent directors hold the majority of the board seats of listed companies.

Although some hold the opinion that outside directors and independent directors facilitate the appropriate oversight and assessment of management because it is difficult for management to affect their decisions, others believe that these directors are of limited use because they are appointed by management and because, compared with inside directors, it is more difficult for them to obtain inside information about the company (Duchin, Matsusaka, \& Ozbas, 2010; Jensen, 1993). Therefore, some prior studies have conducted 
empirical analyses of the impact of outside directors and independent directors on executive compensation levels at U.S. corporations (Boyd, 1994; Core, Holthausen, \& Larcker,1999). It has been pointed out that analyzing the impact of the board's composition on executive compensation poses the endogenous problem of whether executive compensation is actually affected by the board's composition or whether it is in fact affected by other, unobservable factors (Hermalin $\&$ Weisbach, 2003). Therefore, Chhaochharia and Grinstein (2009) looked at exogenous factors by examining increases in the number of independent directors and how this affects the level of executive compensation. Specifically, their analysis avoided the endogenous problem by examining cases after the regulatory changes of 20022003 that required a majority of public companies' corporate boards consist of independent directors. Their findings suggested that the increase in independent directors that was caused by the regulatory changes had a negative impact on executive compensation levels.

However, Guthrie, Sokolowsky, and Wan (2012) were critical of this study, saying that outliers in the sample had had a major impact on the analytical results, and they asserted that excluding these outliers from the analysis would actually mean that the negative impact of the increase in independent directors that was caused by the legislation would no longer be statistically significant.

It therefore remains inconclusive as to whether independent directors have an impact on executive compensation at U.S. companies. Furthermore, although some studies have been done on whether outside directors have an impact on executive compensation at Japanese companies, few have considered the effectiveness of independent directors (Arikawa, 2004; Basu, Hwang, Mitsudome, \& Weintrop, 2007; Miyajima \& Ogawa, 2012; Sakawa \& Watanabe, 2009). Therefore, this paper follows the research of Chhaochharia and Grinstein (2009) in analyzing what impact an increase in independent directors has had on executive 
compensation at Japanese companies.

\section{Method}

This paper analyzes the changes in executive compensation at Japanese companies since the Corporate Governance Code released in June 2015 required companies to have at least two independent directors (Tokyo Stock Exchange, 2015). Chhaochharia and Grinstein (2009) took executive compensation to be the total compensation of the $\mathrm{CEO}$, including base salary, bonus, stock options, and the like. However, Japanese companies do not disclose the individual compensation of the CEO and other executives unless their aggregate compensation is at least 100 million yen. Therefore, this paper uses the average compensation of internal directors, calculated as their total compensation divided by their number, as a proxy for executive compensation. We obtained the data on average compensation for inside directors from the Securities Reports of the companies in the sample.

Because the Corporate Governance Code requiring listed companies to appoint at least two independent directors was announced in June 2015, we assumed that companies that did not have at least two independent directors prior to June 2015 had to increase their independent directors due to the regulatory change. We obtained the data on the number of independent directors at each company from Bloomberg.

Other factors besides the number of independent directors could also affect the level of executive compensation, including the size of the company, corporate performance, and the CEO's influence. This is why Chhaochharia and Grinstein (2009) used the control variables of sales as a proxy for company size, ROA and annual stock return as proxies for corporate performance, and the CEO's tenure in office as a proxy for the CEO's influence. This paper uses these same 
variables as control variables. Data on sales were obtained from Nikkei NEEDS MT data on sales and operating income. For ROA, we used net income attributable to parent company shareholders divided by total assets, as obtained from Nikkei NEEDS MT. Data on annual stock returns came from Bloomberg. Although Chhaochharia and Grinstein (2009) used only the CEO's tenure as a control variable, we used the chairperson's tenure in office as a control variable because Japanese companies use chairman, president, or other titles instead of CEO. We obtained the data on chairpersons' tenure from Bloomberg, and if it was not available there, we used the company's Securities Report.

The observation period was six years, consisting of three years before and three years after the Corporate Governance Code was released in June 2015. Specifically, for companies with a March 31 fiscal year end, we used data from the year ending March 31, 2013, through the year ending March 31, 2018, and for companies with a December 31 fiscal year end, we used data from the year ending December 31, 2012, through the year ending December 31, 2017. The sample consisted of 438 non-financial companies belonging to the TOPIX 500 as of March 31, 2012. Per the regulations, if a company is a "Company with a Nominating Committee, etc." or a "Company with an Audit and Supervisory Committee," it needs to have at least two independent directors (Takahashi, 2016). As a result, we excluded from the sample 23 companies that became companies with a nominating committee and 77 companies that became companies with an audit and supervisor committee during the observation period. We also excluded from the sample 15 firms that delisted during the observation period and 1 firm for which we could not obtain earnings data because it went public in 2011. The final sample consisted of 322 firms, and the number of observations was 1,932. Table 1 gives descriptive statistics for each variable for the companies in the sample. Those companies that had at least two 
Table 1. Descriptive statistics

\begin{tabular}{|c|c|c|c|c|c|c|}
\hline Fiscal year & 2012 & 2013 & 2014 & 2015 & 2016 & 2017 \\
\hline $\begin{array}{l}\text { Number of } \\
\text { independent } \\
\text { directors }\end{array}$ & $\begin{array}{l}1.39 \\
(1)\end{array}$ & $\begin{array}{l}1.64 \\
(1)\end{array}$ & $\begin{array}{l}2.08 \\
(2)\end{array}$ & $\begin{array}{l}2.42 \\
(2)\end{array}$ & $\begin{array}{l}2.56 \\
(2)\end{array}$ & $\begin{array}{l}2.69 \\
(3)\end{array}$ \\
\hline Number of directors & $\begin{array}{l}10.63 \\
(10) \\
\end{array}$ & $\begin{array}{l}10.61 \\
(10) \\
\end{array}$ & $\begin{array}{l}10.69 \\
(10) \\
\end{array}$ & $\begin{array}{l}10.67 \\
(10) \\
\end{array}$ & $\begin{array}{l}10.66 \\
(10) \\
\end{array}$ & $\begin{array}{l}10.44 \\
(10) \\
\end{array}$ \\
\hline $\begin{array}{l}\text { Tenure of board } \\
\text { chairman }\end{array}$ & $\begin{array}{l}5.52 \\
(3)\end{array}$ & $\begin{array}{l}6.20 \\
(4)\end{array}$ & $\begin{array}{l}6.25 \\
(4)\end{array}$ & $\begin{array}{l}6.81 \\
(5)\end{array}$ & $\begin{array}{l}6.88 \\
(5)\end{array}$ & $\begin{array}{l}6.69 \\
(4)\end{array}$ \\
\hline ROA (\%) & $\begin{array}{l}3.18 \\
(2.75) \\
\end{array}$ & $\begin{array}{l}3.85 \\
(3.28) \\
\end{array}$ & $\begin{array}{l}4.01 \\
(3.35)\end{array}$ & $\begin{array}{l}3.87 \\
(3.74) \\
\end{array}$ & $\begin{array}{l}4.16 \\
(3.85) \\
\end{array}$ & $\begin{array}{l}4.64 \\
(4.11)\end{array}$ \\
\hline $\begin{array}{l}\text { Annual total stock } \\
\text { return (\%) }\end{array}$ & $\begin{array}{l}4.88 \\
(4.75)\end{array}$ & $\begin{array}{l}22.07 \\
(22.31)\end{array}$ & $\begin{array}{l}21.38 \\
(18.17)\end{array}$ & $\begin{array}{l}34.86 \\
(31.41)\end{array}$ & $\begin{array}{l}-3.76 \\
(-6.199)\end{array}$ & $\begin{array}{l}18.13 \\
(14.76)\end{array}$ \\
\hline $\begin{array}{l}\text { Total inside } \\
\text { directors } \\
\text { compensation } \\
\text { (million yen) }\end{array}$ & $\begin{array}{l}430.70 \\
(350.5)\end{array}$ & $\begin{array}{l}445.37 \\
(377.5)\end{array}$ & $\begin{array}{l}442.95 \\
(373.5)\end{array}$ & $\begin{array}{l}444.84 \\
(363)\end{array}$ & $\begin{array}{l}446.67 \\
(364.5)\end{array}$ & $\begin{array}{l}481.68 \\
(376.5)\end{array}$ \\
\hline $\begin{array}{l}\text { Average inside } \\
\text { directors } \\
\text { compensation } \\
\text { (million yen) }\end{array}$ & $\begin{array}{l}43.52 \\
(35.61)\end{array}$ & $\begin{array}{l}47.01 \\
(38.97)\end{array}$ & $\begin{array}{l}48.55 \\
(41.28)\end{array}$ & $\begin{array}{l}49.73 \\
(42.61)\end{array}$ & $\begin{array}{l}51.66 \\
(42.71)\end{array}$ & $\begin{array}{l}58.41 \\
(46.45)\end{array}$ \\
\hline \multicolumn{7}{|c|}{$\begin{array}{l}\text { Note: The numbers without parentheses are mean and the numbers in parentheses } \\
\text { are median. }\end{array}$} \\
\hline Period & $\begin{array}{l}2012 / 6 \\
- \\
2013 / 5\end{array}$ & $\begin{array}{l}2013 / 6 \\
-2014 / 5 \\
\end{array}$ & $\begin{array}{l}2014 / 6 \\
-2015 / 5 \\
\end{array}$ & $\begin{array}{l}2015 / 6 \\
-2016 / 5\end{array}$ & $\begin{array}{l}2016 / 6 \\
-2017 / 5\end{array}$ & $\begin{array}{l}2017 / 6 \\
-2018 / 5\end{array}$ \\
\hline $\begin{array}{l}\text { Ratio of companies } \\
\text { with two or more } \\
\text { independent directors } \\
(\%)\end{array}$ & 41.92 & 49.69 & 77.95 & 93.78 & 98.13 & 99.07 \\
\hline $\begin{array}{l}\text { Number of companies } \\
\text { with two or more } \\
\text { independent directors }\end{array}$ & 135 & 160 & 251 & 302 & 316 & 319 \\
\hline
\end{tabular}




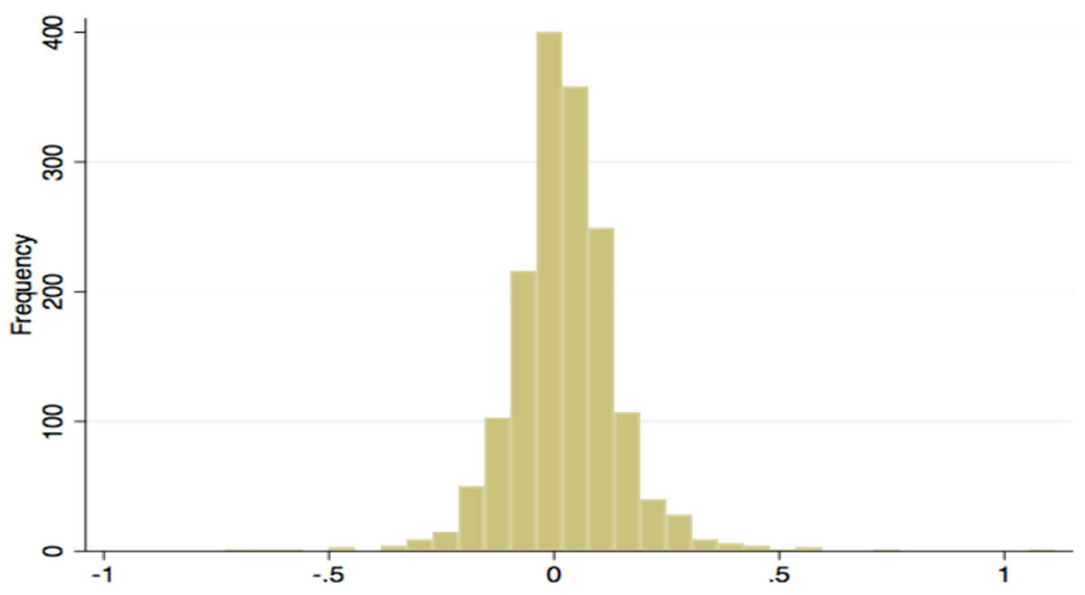

Figure 1. Histogram of changes in average executive compensation for firms

independent directors prior to June 2015 (Comply companies) numbered 251, while those companies that appointed at least two independent directors after June 2015 (Non-comply companies) numbered 71 .

As pointed out in Guthrie et al. (2012), sampling issues could have had a major impact on analytical findings, but we confirmed that there were no outliers, as shown in the histogram of the natural logarithm of annual changes in average executive compensation for the companies in the sample (Figure 1).

To analyze how executive compensation changed at firms that increased their independent directors following the release of the Corporate Governance Code in June 2015, we used the following fixed-effects model similar to that of Chhaochharia and Grinstein (2009). 
Log(Average_Compensation $\left.{ }_{i t}\right)$

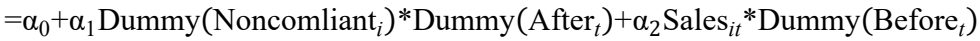

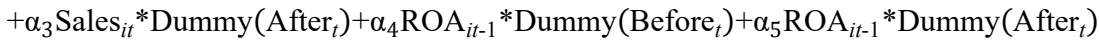

$+\alpha_{6} \operatorname{Return}_{i t-1} *$ Dummy $\left(\right.$ Before $\left._{t}\right)+\alpha_{3}$ Return $_{i t-1} *$ Dummy $\left(\right.$ After $\left._{t}\right)+$ Tenure $_{i t}+$ Fixed Effect $+\epsilon$

$\log \left(\right.$ Average_Compensation $_{i t}$ ) is the natural logarithm of the average compensation of inside directors, calculated as total compensation of inside directors divided by the number of inside directors, at Company $i$ during time $t$. Dummy(Noncomliant $t_{i}$ ) is a dummy variable that is 1 when the number of independent directors at Company $i$ as of June 2015 is less than two. Dummy(Before ${ }_{t}$ ) is a dummy variable that is 1 when time $t$ of the observed value is before June 2015, while Dummy $\left(\right.$ After $_{t}$ ) is a dummy variable that is 1 when time $t$ of the observed value is after June 2015. Sales ${ }_{i t}$ is the natural logarithm of sales for Company $i$ during time $t$. For $\mathrm{ROA}_{i t-1}$, we used the natural logarithm of 1 plus the ROA for Company $i$ in the year prior to time $t$, while for $\operatorname{Return}_{i t-1}$, we used the annual stock return of Company $i$ over the year preceding time $t$. For Tenure ${ }_{i t}$ we used the natural logarithm of 1 plus the tenure of the chairperson of Company $i$ at time $t$.

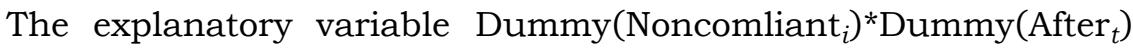
is a dummy variable that is 1 when the observed value is from a Non_comply company after June 2015 . When the coefficient $a_{1}$ of this variable is a negative value, the average compensation of inside directors at the Non_comply company after June 2015 is lower than the average compensation of inside directors at the Non_comply company before June 2015 and the average compensation at Comply companies.

\section{Results}

Table 2 gives that analytical results of the fixed-effects model 
Table 2. Empirical result

\begin{tabular}{|c|c|c|}
\hline Variables & Coefficient & $t$ value \\
\hline 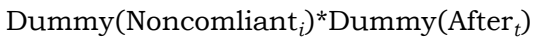 & -0.034 & -1.38 \\
\hline Sales $_{i t}{ }^{*} \operatorname{Dummy}_{\left(\text {Before }_{t}\right)}$ & $0.246^{* * *}$ & 5.16 \\
\hline Sales $_{i t}{ }^{*} \operatorname{Dummy}_{\left(\text {After }_{t}\right)}$ & $0.258^{* * *}$ & 5.43 \\
\hline $\mathrm{ROA}_{i t-1} *$ Dummy $\left(\right.$ Before $\left._{t}\right)$ & $1.878^{* * *}$ & 7.07 \\
\hline $\mathrm{ROA}_{i t-1} *$ Dummy $\left(\right.$ After $\left._{t}\right)$ & $0.780^{* * *}$ & 3.67 \\
\hline $\operatorname{Return}_{i t-1} * \operatorname{Dummy}_{\left(\text {Before }_{t}\right)}$ & -0.001 & -0.17 \\
\hline $\operatorname{Return}_{i t-1}{ }^{*}$ Dummy $_{\left(\text {After }_{t}\right)}$ & $0.013^{* *}$ & 2.08 \\
\hline Tenure $_{i t}$ & $0.027^{* *}$ & 2.44 \\
\hline
\end{tabular}

described above. The coefficient of Dummy(Noncomliant $\left.{ }_{i}\right)$ Dummy After $_{t}$ ) was not statistically significant. This suggests that, similar to the analysis in Guthrie, Sokolowsky, and Wan (2012), increasing the number of independent directors does not affect the level of executive compensation. The coefficients for Sales $_{i t}{ }^{*}$ Dummy $\left(\right.$ Before $\left._{t}\right)$ and Sales $_{i t}{ }^{*}$ Dummy $\left(\right.$ After $_{t}$ ) were statistically significant positive values, showing that companies with high sales have high levels of executive compensation. Also, we observed a strong positive correlation between executive compensation and $\mathrm{ROA}_{i t-1}{ }^{*}$ Dummy(Before ${ }_{t}$ ) as well as $\mathrm{ROA}_{i t-1}{ }^{*}$ Dummy $\left(\right.$ After $\left._{t}\right)$, which suggests that Japanese firms link executive compensation to ROA. The coefficient for Tenure Tit $_{i}$ was a statistically significant positive value in our analysis, showing that executive compensation is elevated at Japanese companies where board chairs have a lengthy tenure. 


\section{Discussion}

Although the coefficient for Dummy(Noncomliant $\left.{ }_{i}\right)$ Dummy $\left(\right.$ After $\left._{t}\right)$ was not statistically significant, it was negative. However, as we can see from Figure 2, the mean for average compensation of inside directors at Non_comply firms is actually rising (the coefficient is negative because the increase is smaller than at Comply firms). Since 2012, both Non-comply firms and Comply firms have seen their ROA go up (Figure 3), so this is probably why executive compensation has been increasing.

However, the impact of corporate financial performance, as shown by ROA, on executive compensation varies widely from company to company. Figures 4, 5, and 6 show the trends in inside directors' compensation by type, calculated by dividing the amount of compensation paid by type of inside director divided by their total number from fiscal 2012 through fiscal 2017, for three companies

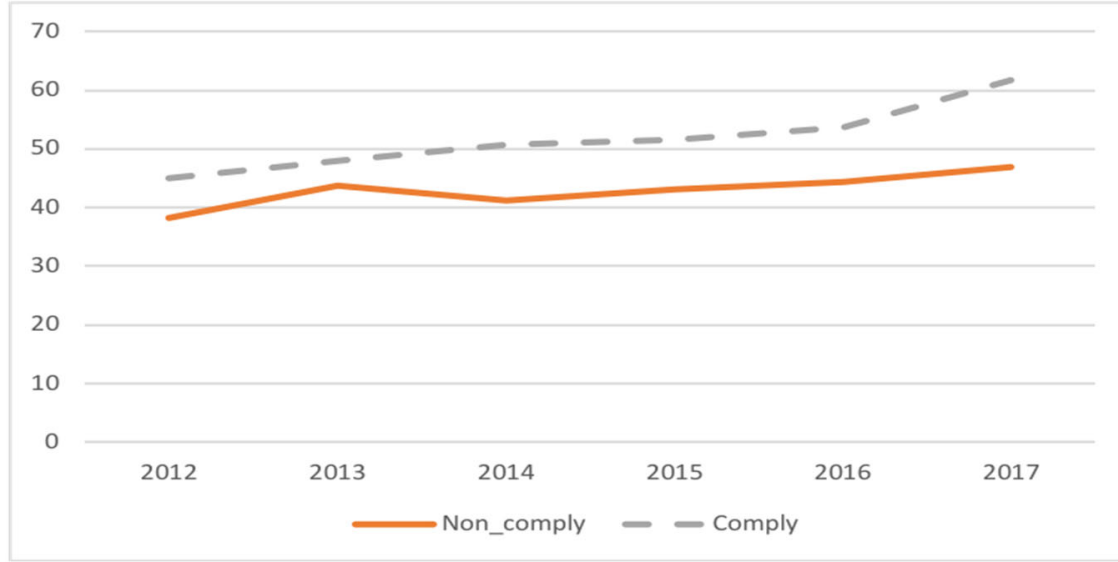

Figure 2. Average executive compensation (million yen) trends

Note: Non_comply is mean of companies which appointed two or more independent directors after June 2015 and Comply is mean companies which appointed two or more independent directors before June 2015. 


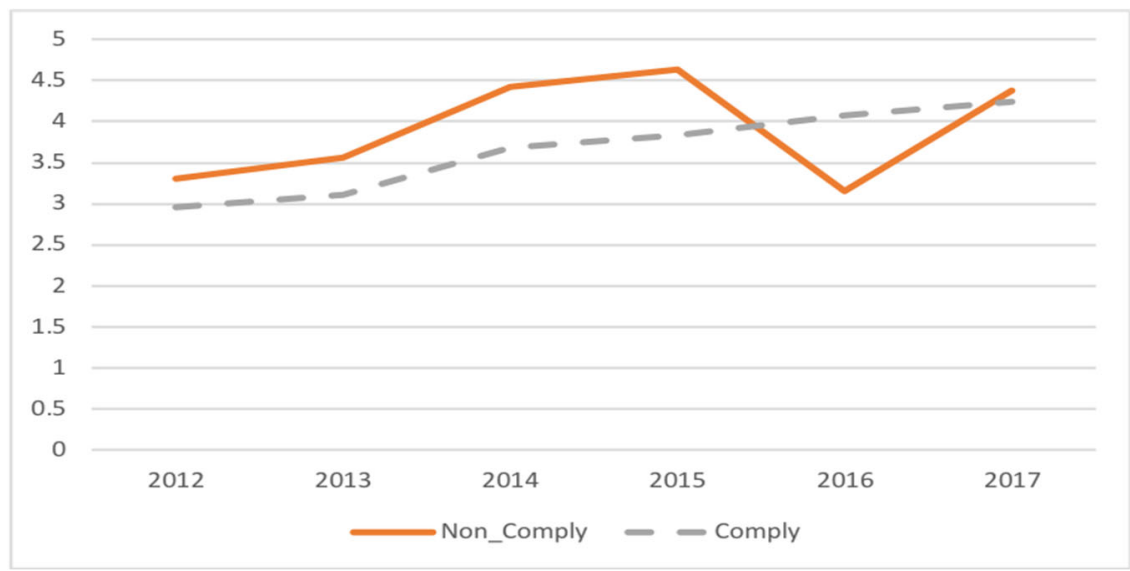

Figure 3. Average ROA (\%) trends

Note: Non_comply is mean of companies which appointed two or more independent directors after June 2015 and Comply is mean companies which appointed two or more independent directors before June 2015.

that are mobile network operators providing mobile phone services-Softbank, KDDI, and NTT Docomo. Stock compensation is the total compensation in the form of both stock options and restricted stock. Also, these three companies did not pay any directors' retirement bonuses between fiscal 2012 and fiscal 2017.

The levels of basic salary and bonus shown in Figures 4, 5, and 6 showed little movement at any of the three companies during this period, so pay levels at each company did not change much. At the same time, the amount of stock compensation, both comparatively between companies and within each company, varied greatly from year to year. Therefore, even companies in the same sector have different compensation structures in terms of the ratio of salaries and bonuses (as opposed to stock compensation) in inside directors' average compensation, and these structures affect the amount of executive compensation from company to company and from year to 


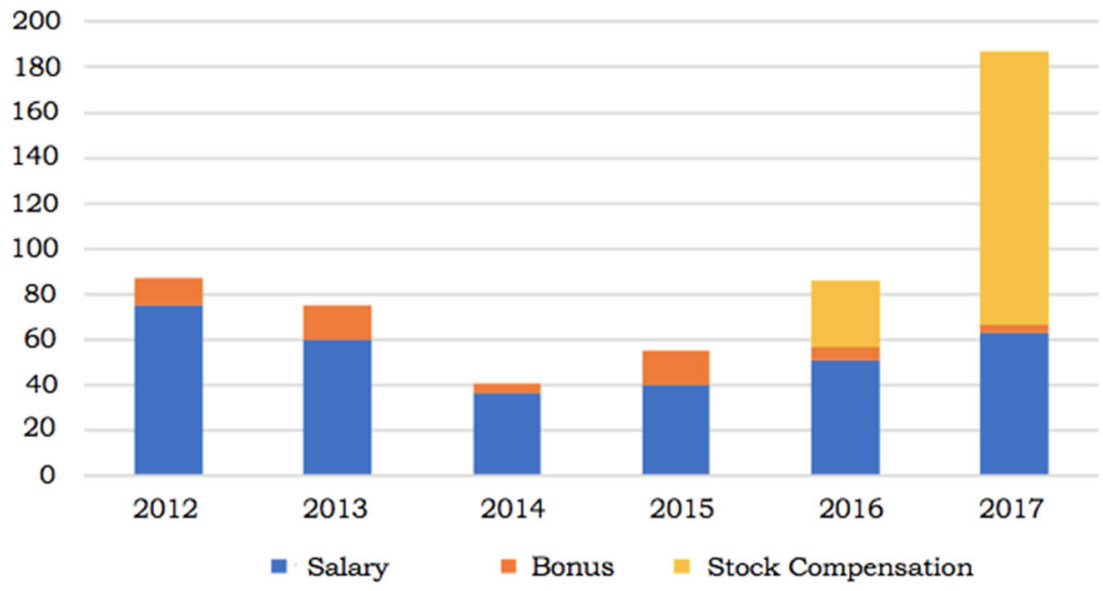

Figure 4. Classified average executive compensation in Softbank

Note: Vertical axis indicates the amount of average executive compensation and horizontal axis indicates fiscal year.

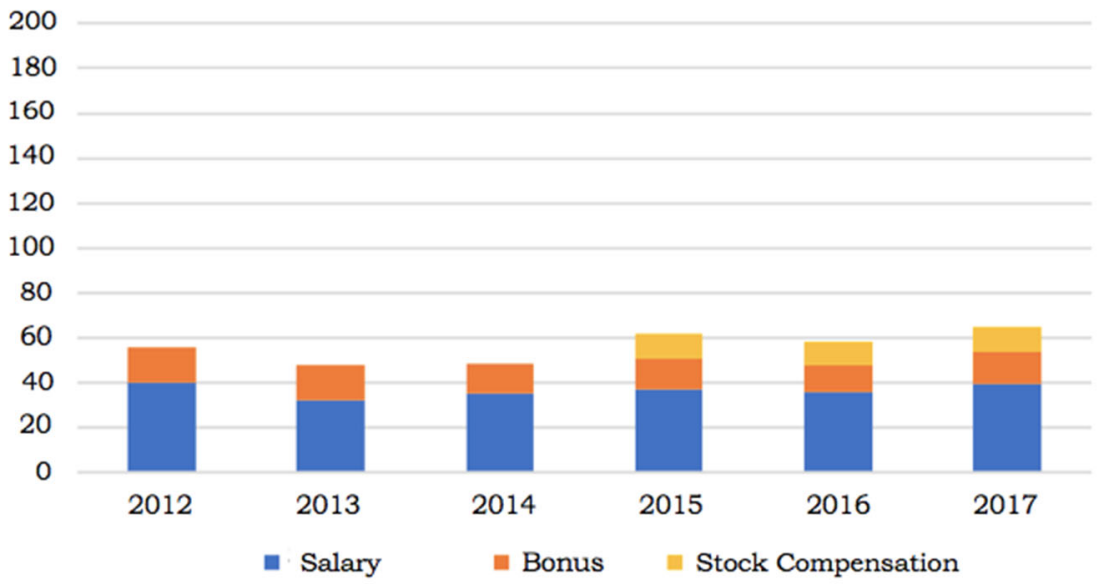

Figure 5. Classified average executive compensation in KDDI

Note: Vertical axis indicates the amount of average executive compensation and horizontal axis indicates fiscal year. 


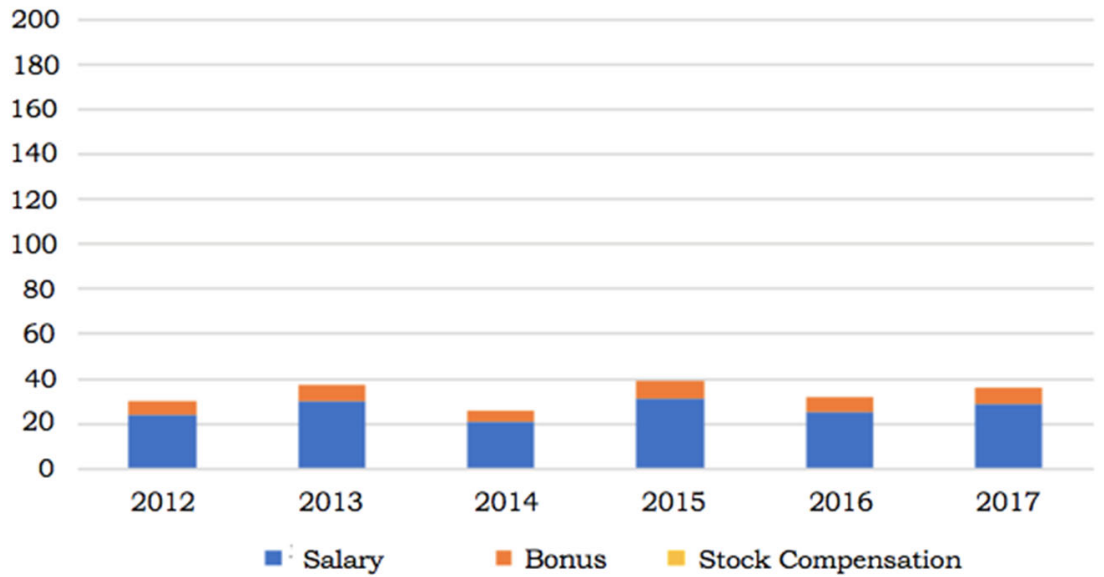

Figure 6. Classified average executive compensation in NTT Docomo

Note: Vertical axis indicates the amount of average executive compensation and horizontal axis indicates fiscal year.

year. In fact, Softbank's ROA is lower than that of either NTT Docomo or KDDI, but it has had a higher proportion of stock compensation in its compensation structure, which makes the average compensation of its inside directors the highest among the three companies. In other words, the compensation structure was the determining factor.

\section{Conclusion}

Following up on Chhaochharia and Grinstein (2009), this paper analyzed whether the June 2015 Corporate Governance Code requiring listed companies to appoint at least two independent directors has changed executive compensation at firms that have increased their number of independent directors. The analytical results of our fixed-effects model found that an increase in the number of independent directors did not have a statistically significant effect on executive compensation. In fact, average 
executive compensation rose during the observation period at firms that increased their number of independent directors following the regulatory change. This suggests that regulations for appointing independent directors do not serve to lower executive compensation. In other words, the recent trend of Japanese firms' appointing independent directors is not due to this practice's success in the U.S. in strengthening supervision of management, but rather is due to institutional isomorphism (Aizawa, 2018).

At the same time, major variations exist within industrial sectors on the amounts and percentages of salary and bonuses as opposed to stock compensation in total compensation, and these differences in compensation structures have generated differences in executive compensation levels among companies. In other words, executive compensation levels are affected more by the compensation structure that has been established by each individual company than by such factors as the number of independent directors or corporate financial performance. Prior studies on executive compensation have focused mainly on such factors as firms' structures of governance or their financial performance. Our analytical results, however, illustrate the importance of analyzing executive compensation by focusing on the compensation structure established by each individual company. A key topic for a future study could be to analyze which factors affect each company's compensation structure. However, under the existing disclosure regulations, companies only disclose limited information on how they determine compensation, so it is difficult to find out the specifics of how compensation is set, and the decisionmaking process involved. We thus anticipate a strengthening of the disclosure regulations regarding how compensation is determined to improve the transparency of information on executive compensation. 


\section{Acknowledgments}

This work was supported by JSPS Grant-in-Aid for Publication of Scientific Research Results, Grant Number JP16HP2004.

\section{References}

Aizawa, A. (2018). Institutional isomorphism in Japanese firms' compliance activities. Annals of Business Administrative Science, 17, 5768. doi: 10.7880/abas.0180130a

Arikawa, Y. (2004). Keieisha insentive no corporate governance eno eikyo [The impact of management incentives on corporate governance]. Nissei Kisoken Shoho, 33, 133-154 (in Japanese).

Basu, S., Hwang, L., Mitsudome, T., \& Weintrop, J. (2007). Corporate governance, top executive compensation and firm performance in Japan. Pacific-Basin Finance Journal, 15(1), 56-79.

Boyd, B. K. (1994). Board control and CEO compensation. Strategic Management Journal, 15(5), 335-344.

Bui, T. (2020, January). Executive compensation and independent directors in Japan. Paper presented at ABAS Conference 2020 Winter, University of Tokyo, Japan.

Chhaochharia, V., \& Grinstein, Y. (2009). CEO compensation and board structure. Journal of Finance, 14(1), 231-262.

Core, E. J., Holthausen, W. R., \& Larcker, F. D. (1999). Corporate governance, chief executive officer compensation, and firm performance. Journal of Financial Economics, 51(3), 371-406.

Duchin, R., Matsusaka, G. J., \& Ozbas, O. (2010). When are outside directors effective? Journal of Financial Economics, 96(2), 195-214.

Fama, E. F. (1980). Agency problems and the theory of the firm. Journal of Political Economy, 88(2), 288-307.

Fama, E. F., \& Jensen, M. N. (1983). Separation of ownership and control. Journal of Law and Economics, 26(2), 301-325.

Guthrie, K., Sokolowsky, J., \& Wan, K. (2012). CEO compensation and board structure revisited. Journal of Finance, 67(3), 1149-1168. 
Hermalin, H. B., \& Weisbach, S. M. (2003). Boards of directors as an endogenously determined institution: A survey of the economic literature. Economic Policy Review, 9(1), 7-26.

Jensen, M. (1993). The modern industrial revolution, exit, and the failure of internal control systems. Journal of Finance, 48(3), 831-880.

Maruyama, M. (2006). Corporate internal central and corporate governance from the experience of Enron/Worldcom cases. Journal of Japan Society for Safety Engineering, 45(4), 212-219.

Miyajima, H., \& Ogawa, R. (2012). Nihon kigyo no torishimariyakukai kosei no henka wo ikani rikaisuruka: Torishimariyakukai kosei no ketteiyouinn to shagaitorishimariyaku no donyukouka [How do you understand the changing board composition of Japanese companies? Determinants of the composition of the Board and the effects of introducing outside directors]. (RIETI Policy Discussion Paper Series 12-P-013). Research Institute of Economy, Trade and Industry (in Japanese).

Sakawa, H., \& Watanabe, N. (2009). Keieisha houshu to torishimariyakukai no keiei kanntoku kinou ni tuite no kenshou [Managerial compensation structure and corporate governance mechanism in Japan]. Review of Monetary and Financial Studies, 29, 66-83 (in Japanese).

Takahashi, N. (2016). Keiei no saisei [Managerial renaissance] (4th ed.). Tokyo, Japan: Yuhikaku (in Japanese).

Tokyo Stock Exchange (2015). Japan's Corporate Governance Code. Retrieved from https://www.jpx.co.jp/news/1020/ nlsgeu000000xbfx-att/code.pdf

Tokyo Stock Exchange (2019). Appointment of independent directors and establishment of nomination and remuneration committees by TSElisted companies. Retrieved from https://www.jpx.co.jp/english/ listing/others/ind-executive/tvdivq0000001j9jatt/b5b4pj000002zfp5.pdf 